\title{
Karl Barth on the Irresistible Nature of Grace
}

The doctrine of irresistible grace stands as one of the most divisive doctrines in the church since the Reformation. As popular debates over this doctrine continue between 'Arminians' and 'Calvinists', attention has been devoted to the question of whether grace irresistibly effects human salvation and conversion. The problem with this anthropocentric focus is that it can risk reducing 'grace' to an instrument of human change. If this happens, Christians can lose sight of a theology of grace in which grace is associated with the beneficent disposition and action of God towards humanity.

In what follows, I begin by looking at how Karl Barth provides us with a helpful way forward for understanding the irresistible nature of grace by associating grace primarily with God's free and beneficent activity towards creation. Focusing on Barth's Church Dogmatics, I think through the significance of the priority he gives to the election of grace over the being and existence of the creature. ${ }^{1}$ Finally, I consider the implications of Barth's theology of grace for human subjectivity by addressing the following questions: (1) how does Barth affirm the constancy of God's irresistible grace without presenting God as the 'author of evil'?; (2) is irresistible grace compatible with the free activity of the creature?; (3) is Barth committed to a compatibilist notion of human freedom?; and lastly (4) what does it mean to describe the call to faith as irresistible?

\section{Moving Beyond Popular Formulations of Irresistible Grace}

At a more popular level, the doctrine of irresistible grace has often served to emphasise the irresistible agency of God for the purposes of human conversion and salvation. Following the Synod of Dordt, this doctrine has found its home within the 'Calvinist' tradition, with advocates such as Charles Hodge, Charles Spurgeon, James Orr, B.B. Warfield, John Murray, Loraine Boettner, J. I. Packer, Bruce Ware, and Matthew Barrett. ${ }^{2}$ While many other Reformed figures

\footnotetext{
${ }^{1}$ Karl Barth, Church Dogmatics, ed. G.W. Bromiley and T. F. Torrance (Edinburgh: T\&T Clark, 1956-77) (hereafter abbreviated $C D$ ). When referencing the German, I reference Die Kirchliche Dogmatik (Munich: Chr Kaiser 1932 and thereafter Zürich: EVZ, 1938-1965) (hereafter abbreviated KD).

${ }^{2}$ See Charles Hodge, Systematic theology, ed. Edward Gross (Grand Rapids: Baker Book House, 1988), 429; Charles Spurgeon, "The New Heart," http://www.spurgeon.org/sermons/0212.php; James Orr, The Progress of Dogma (1901) (Cambridge: James Clarke \& Co., 2001), 150; B.B. Warfield, Calvin and Calvinism, (New York: Oxford University Press, 1931), 359; J. I. Packer, "Introductory Essay," in John Owen, The Death of Death in the Death of Christ (London: Banner of Truth, 1959), 3-4; and Bruce Ware, "Effectual Calling and Grace," in Still Sovereign, ed. Thomas R. Schreiner and Bruce Ware (Grand Rapids: Baker Books, 2000), 203-4, 208, 210; Loraine Boettner, The Reformed Doctrine of Predestination (Phillipsburg: Presbyterian and Reformed Publishing
} 
such as Jonathan Edwards have described the disputes over irresistible grace as "perfect nonsense," 3 this doctrine continues to find popular expression in the enormously influential neo-Calvinism of John Piper, Albert Mohler, and Mark Driscoll. ${ }^{4}$ This new movement is currently one of the most influential Christian movements in the modern world, being described by Time magazine as one of the ten ideas changing the world right now (in 2009). ${ }^{5}$

Following in the tradition of the Synod of Dordt (1618-19), neo-calvinists typically endorse the kind of definition articulated by Donald McKim:

Irresistible grace means that God gives the gift of grace to the elect in an irresistible way; they are not able to refuse it. They are sinful; so God changes their whole lives, including their wills, by the power of the Holy Spirit. God grants them the gift of faith so that they believe in Jesus Christ as Lord and Savior. If they are the elect, they will be irresistibly drawn into salvation through faith in Christ. ${ }^{6}$

The danger with accounts such as this is that they can invite a popular perception of grace as an impersonal gift that God passes on to the elect, with the effect of bestowing new properties onto them. For example, by renewing the mind, grace gives the elect healthy affections that are properly ordered towards God. The giving of this gift involves two events: first, the event of its being given by God (the communication of sufficient grace); and, second, the event of its being appropriated by the elect (the irresistible operation of this grace). ${ }^{7}$ The gift of grace is regarded as irresistible because, in the second event, the elect are unable to refuse it. That is, they are unable to refuse the specific way in which grace draws them into their salvation in Christ, for example, by giving them the gift of faith. By asserting this position, the so-called 'Calvinists' distinguish themselves from the 'Arminians' (from Jacob Arminius himself to William Laud,

Company, 1932), 171; John Murray, "Irresistible Grace," in Soli Deo Gloria: Essays in Reformed Theology, ed. R.C. Sproul (Phillipsburg: Presbyterian and Reformed Publishing, 1976); Matthew Barrett, Salvation by Grace: The Case for Effectual Calling and Regeneration (Phillipsburg: P\&R Publishing, 2013).

${ }^{3}$ Jonathan Edwards, The Works of Jonathan Edwards 13: The "Miscellanies," 1-500, ed. Thomas A. Schafer (New Haven: Yale University Press), 170.

${ }^{4}$ In this context, as is well known, the notion of irresistible grace is most commonly associated with the ' $\mathrm{I}$ ' in the acronym TULIP of five-point 'Calvinism'. See John Piper, "Irresistible Grace," What we Believe About the Five Points of Calvinism, www.desiringgod.org/resource-library/articles/what-we-believe-about-the-five-points-ofcalvinism\#Grace; and Schreiner and Ware, ed., Still Sovereign, 15, 19, 52, 203-27.

5 David Van Biema, “The New Calvinism,” www.time.com/time/specials/packages/article/0,28804,1884779_ 1884782_1884760,00.html.

${ }^{6}$ Donald McKim, Introducing the Reformed Faith (Louisville: Westminster John Knox Press, 2001), 183.

7 See William Den Boer, "Defense or Deviation?," in Revisiting the Synod of Dordt, ed. Aza Goudriaan and Fred van Lieberg (Leiden: Brill, 2011), 43. 
John and Charles Wesley, and Adam Clarke, to Grant Osborne, John Sanders and Roger Olson) who maintain that grace "is not irresistible:" that it does not bring about conversion and salvation irresistibly. ${ }^{8}$

It is not the 'to and fro' of this popular debate that will be the concern of this essay. What I shall address, in dialogue with Barth, is the specific tendency for theologies of grace to focus on the effects that grace has on particular human beings. This inclination is apparent, I suggest, in the accounts of grace that collapse the irresistibility and efficaciousness of grace. ${ }^{9}$ The danger here is that we end up forgetting that God's grace is God's grace; that it is God's free, personal, and beneficent disposition and action. Instead, grace comes to be viewed primarily as 'a means to justification', 'a means to salvation', 'a means to conversion' etc. In short, grace is associated with Christ's atoning work as the means to overcome sin, and with the Spirit's sanctifying work as the means to appropriate salvation to individual human existence. Under these circumstances, a person's relationship with God can become a means to an end rather than the end in itself. Grace is not primarily understood as the way that God lovingly relates to persons but as the means to transform persons into saved persons: persons who possess the capacity to follow the will of God. In this way, grace takes on a uniformity that centres on the salvific transformation of the individual human subject. And discussions of the irresistibility of grace do not focus on the irresistibility of God's free activity but on the human subject's inability to resist assuming the 'saved qualities' that grace bestows upon them. That is, they revolve around the existential transformation of sinful persons into saved persons.

Consequently, we end up with an understanding of grace that Barth also detects in the Roman Catholic Dogma of Bernhard Bartmann — where grace is interpreted "as a third element mediatorial between God and His creatures." 10 On such an account, it can almost seem as if God engages the world by imparting a 'gift of grace' that functions as the agent of human salvation. With this perception in place, the theology of grace can also end up focusing on our experience of its immediately visible effects, e.g. when a person becomes a Christian. And this

\footnotetext{
${ }^{8}$ Articuli Arminiani sive Remonstratia IV, in Creeds of Christendom, ed. Philip Schaff (New York: Harper and Brothers, 1919), 3:547; see also Roger E. Olson, Arminian Theology: Myths and Realities (Downers Grove: InterVarsity, 2006), 53-4; Clark H. Pinnock, ed., The Grace of God, the Will of Man (Grand Rapids: Zondervan, 1989), 40, 171, 249.

${ }^{9}$ There has been a tendency in neo-calvinism to associate irresistible grace with the doctrine of effectual calling and grace as it is put forward by the Westminster Confession, "Of Effectual Calling," 10.1. See, for example. Bruce Ware, "Effectual Calling and Grace," in Still Sovereign, 203-4, 208, 210; David Steele and Curtis Thomas, The Five Points of Calvinism Defined, Defended, Documented (Phillipsburg: Presbyterian and Reformed Publishing Company, 1963), 48-49; Matthew Barrett, Salvation by Grace: The Case for Effectual Calling and Regeneration (Phillipsburg: P\&R Publishing, 2013).

${ }^{10} \mathrm{CD} I I / 1,353$, with reference to Bernhard Bartmann, Lehrbuch der Dogmatik, Vol. II (Freiburg: Herder \& Co., 1929), 3-4.
} 
can invite unhelpful speculation about which particular persons are the objects of grace: i.e. is it those who are wilfully disposed to receive the gift of grace or is it those whom God has elected to save by granting them the gift of grace?

The mistake of these approaches, for Barth, is that they do not first turn to the person of Jesus Christ to understand God's grace towards humanity - to understand the covenant of grace within which God creates and sustains the creature. By turning first to Jesus Christ to understand God's grace, we do not base our theology of grace on "the evident contrast between those who through the Church hear the Gospel and those who never have the opportunity to hear it at all; or, again, between those who hear obediently and with profit, and so to salvation, and those who hear with open hostility, or without any result at all and so finally to condemnation."11 Instead, we turn to the one in whom there is unity between God and humanity, and, therefore, to the one in whom grace is fully mediated to humanity, irrespective of the diversity of human beliefs, attitudes, and behaviour.

Understood christologically, for Barth, the enactment of grace is not attached to the diverse range of effects that we suppose it to have on particular sinful human beings. Rather, grace is attached to God's action in and through Christ. This position finds close alignment with Paul whose "characteristic stance," John Barclay writes, "is to associate the grace of God with the Christ-event." 12 He continues:

The foundational event to which he [Paul] calls the Corinthians' attention is 'the grace of our Lord Jesus Christ' (2 Cor. 8.9), and there is little doubt what (or whom) he is referring to by God's 'inexpressible gift' (2 Cor. 9.15). In discussing the figure of Adam, Paul identifies the grace of God not in the constitution or capacity of humanity in general, but in the overflowing of the 'gift in grace' of the one man Jesus Christ (Rom. 5.12-21). Although the Christevent is the expression of 'the grace of God' (Gal. 2.21), there is no gap between 'Christ' and 'God' in this regard: a historical moment becomes the definitive instance of divine grace which fundamentally alters the relationship between humanity and God. Christ is not, then, a new and substitutable 'label' for divine

\footnotetext{
${ }^{11}$ CD II/ $/, 38$; see also 38-44.

${ }^{12}$ John Barclay, “'By the Grace of God I am What I am:' Grace and agency in Philo and Paul," in Divine and Human Agency in Paul and his Cultural Environment, ed. John Barclay and Simon Gathercole (London: T\&T Clark, 2007), 150.
} 
grace, but stands at a very particular moment when divine grace changes the history of the world, throwing all else, before and after, into a different light. ${ }^{13}$

For Paul, as for Barth, each enactment of grace in time is determined by the unconditional freedom of God. "God is the source of the necessary grace." 14 Soteriologically, this means that grace concerns the saving action of God that is followed by an imperative Christian response, which is "an urgent corollary." 15 So, for both of them, the appropriate response to God's grace is made in Christ, in whom the believer is "continually reshaped by the event of grace with unpredictable results." 16 There is, therefore, no foreseeable uniformity in the impact that the grace of God has on a person's life in Christ.

For Barth, God's saving action finds its fulfillment not in subjective human transformation but in the divine-human history that is established in the life, death, and resurrection of the incarnate Son. ${ }^{17}$ In this way, Jesus Christ is not simply the means to salvation but the ends of salvation. Salvation is thus in and through Christ rather than by way of Christ. This emphasis on the objectivity of Christ is at the heart of Barth's theology of grace. For Barth, as Keith Johnson writes, the covenant of grace "is not a programme but a person: Jesus Christ." 18 It is Jesus Christ who is the fulfilment of the relationship between God and humanity, and, therefore, he is the one in whom persons participate in the fullness of covenant relationship with God. As the fulfilment of the covenant of grace, Jesus Christ not only unites grace with humanity but also perfectly appropriates it for humanity. That is, he achieves a mediation between divine and human agency, between God's grace and human works, that holds no reality apart from the God-human unity that is created in him.

Apart from Jesus Christ, for Barth, there is no union between the gracious activity of God and the contingent activity of individual creatures. To suppose otherwise, would be to misunderstand the grace of God. It "would be to forget that the activity of God is the activity of His continually free grace, an activity from above downwards". ${ }^{19}$ By making sure that grace is properly associated with the unconditional and irresistible activity of God, in distinction from

\footnotetext{
${ }^{13}$ Barclay, "By the Grace of God," 150.

${ }^{14}$ Barclay, "By the Grace of God," 153.

${ }^{15}$ Barclay, "By the Grace of God," 151.

${ }^{16}$ Barclay, "By the Grace of God," 150.

${ }^{17}$ CD IV/2, 64-65.

${ }^{18}$ Keith Johnson, Karl Barth and the Analogia Entis (London: T\&T Clark, 2010), 206.

${ }^{19} \mathrm{CD} I I I / 3,149$. For Barth, there is no "absorption and assimilation of creaturely activity into the divine," and no suggestion of any "disintegration and destruction of the creaturely in favour of the divine." God does not suppress the variety, autonomy and particularity of creaturely activity in face of His own. Instead, the grace of God seeks the affirmation, deliverance, and glorification of the creature. CD III/3, 149.
} 
human activity, Barth develops a theology of grace that is preserved from any Hegelian system that unites God and humanity. His theology of grace denies "all theories of emanation and infusion"; it is safeguarded "against pantheism and monism"; and it is assured "against the fear that little and ultimately nothing will be left for the nature and activity and freedom and responsibility of the creature". ${ }^{20}$ Barth refuses to speak of "the operation of God in mechanical or emanationist terms"- a tendency he saw arising in the overly systematic 'Calvinism' of Johannes Coccejus and his followers. ${ }^{21}$

Given his resistance to any confusion between divine and human agency, Barth affirms that Christians can only live in correspondence to the grace that is mediated to humanity in the person of Jesus Christ, through the power of his Holy Spirit. Yet, while Barth stresses the objectivity of grace in the person of Jesus Christ, he does not disregard the implications of grace for human subjectivity. For Barth, human beings are drawn to participate subjectively in the objective reality of Jesus Christ by the grace of the Holy Spirit (der Gnade des Heiligen Geistes). ${ }^{22}$ This subjective realisation does not bring about any further fulfilment of the covenant of grace but it does enable persons to participate in its fulfilment, and it does so in correspondence with God's Word. Thus, in line with Reformed orthodoxy, Barth maintains the inseparability of God's Word and Spirit. It is Jesus Christ who sends the Holy Spirit to particular persons to draw persons into the human-to-human relationship with God that is mediated through him. Grace, therefore, is never dispensed to humanity in abstraction from the humanity that God assumes in Jesus Christ; it is not "a transmitted material condition."23. Rather, grace encounters particular persons in the event of a personal address. Grace encounters persons as the active presence of the triune God whose love encounters creation, in and through Christ, by the outpouring of the Holy Spirit. ${ }^{24}$ Under these circumstances, grace is irresistible because human beings are neither the agents of its performance nor the agents of its fulfilment. Grace, therefore, is beyond human control.

\footnotetext{
${ }^{20} \mathrm{CD} I I I / 3,149$.

${ }^{21}$ CD III/3, 140.

${ }^{22}$ When Barth refers to the "grace of the Holy Spirit," he is referring to the action of the Holy Spirit as an expression of the free and unchanging grace of the triune God. Therefore, when Barth uses this phrase, he is not referring to a grace that is detached from the unified action of God's Word and Spirit.

${ }^{23} C D I / 1,40-42$.

${ }^{24} C D I / 1,67$.
} 


\section{The Election of Grace}

Undergirding Barth's theology of grace is his doctrine of the election of grace, which he describes as "the sum of the Gospel". ${ }^{25}$ The function of this doctrine is "to bear basic testimony to eternal, free and unchanging grace as the beginning of all the ways and works of God." ${ }^{26}$ In election, God elects himself to be creator: the only creator who creates with a grace and purpose that is neither constrained nor conditioned by the contingent activity of the creation that he freely creates.

Also, in election, God elects himself to be the covenant God who creates humanity to be his covenant-partner in Jesus Christ, who is both the subject and object of election. So, for Barth, it is in Christ that persons participate in covenant fellowship with God. In the history of this covenant, God's decision for humanity "precedes every creaturely decision:" "Over against all creaturely self-determination it is pre-determination". ${ }^{27}$ Nothing precedes the grace of God, and so "God owes His grace to no one, and... no one can deserve it." ${ }^{28}$ In this way,

[God] constitutes [setzt] Himself the Lord of the covenant. He is, therefore, its free author. He gives it its content and determines its order. He maintains it. He directs it to its goal. He governs it in every respect. It is His decision that there is a covenant-partner. It is also His decision who this partner is, and what must befall him. ${ }^{29}$

Barth, however, not only stresses that God is lord of the covenant but also that God wills, expects, and demands something from his covenant-partner. God makes the creature actively responsible in its position as covenant partner. Barth asks rhetorically: "How could God draw him [the creature] to Himself, as He does, without making him responsible?" He then writes: "God constitutes this 'being responsible' the whole meaning of his [the creature's] existence."30 Yet Barth does not think that God leaves the creature to be responsible in and of itself. In the incarnation, God gives the human representation in Christ so that in and through Christ the human can live as a child of God. Again, however, God remains sovereign throughout this God-

\footnotetext{
${ }^{25} \mathrm{CD} I \mathrm{II} / 2,3$.

${ }^{26} C D I I / 2,3$.

${ }^{27} \mathrm{CD} I I / 2,19$.

${ }^{28} \mathrm{CD} I I / 2,10-11$.

${ }^{29} \mathrm{CD} \mathrm{II/2}, 9$.

${ }^{30} \mathrm{CD} I I / 2,9$.
} 
humanward movement, to the extent that all that occurs in the establishment of God's covenant purposes proceeds from God's side and takes place fundamentally in Jesus Christ, our high priest.

This raises the oft-omitted question as to what it means to participate in Christ? Participation in or koinonia with Christ entails "a relationship between two persons in which these are brought into perfect mutual co-ordination within the framework of a definite order, yet with no destruction of their two-sided identity and particularity, but rather in its confirmation and expression." ${ }^{11}$ This is made possible in the koinonia of the Holy Spirit who gives persons to share in the being of Jesus Christ and become transformed by who Christ is. Participation in Christ, therefore, does not mean that a person is turned into "a kind of second Christ". ${ }^{32}$ For Barth, the divinity of Jesus Christ makes him totally unique from non-divine persons. Indeed, he holds that Jesus retains a certain isolation (Einsamkeit) from all other human subjects. Therefore, the Christian faith does not involve conflation into Christ. The agencies of particular human beings are not subsumed into Christ's agency, nor are they taken over by the Spirit. Nonetheless, Barth does think that the faith of the Christian is defined by a "pure receptivity in relation to its object". ${ }^{33}$ As such, the Christian can only ever imitate, reflect, and repeat the one who is perfect. And when she does so, she is only similar to Jesus Christ "in the greatest dissimilarity" and her faith "can never be more than an analogy". ${ }^{4}$ That is, the Christian's faith is not Jesus Christ's faith and yet it cannot be abstracted from Christ. The Christian's faith is "a concrete correspondence to the One in whom it believes" and it is so as "a real apprehension of his real being in Christ." 35

What is unambiguously clear, for Barth, is that God does not elect human beings to be their own masters, to be lords over their relationship with God. While God can create a situation in which human beings appear to be their own lords, God cannot stop them from being contingent, and, moreover, cannot make the outworking of his eternal purposes contingent upon the essentially subsequent activity of the creature. God can, of course, purposefully give creatures a level of independence, can allow them to act in their own way in a given set of circumstances, and can make their actions decisive for how God interacts with the history of

\footnotetext{
${ }^{31} C D$ IV/3, 535.

${ }^{32} C D I V / 1,769$. As such, Barth would disagree with Luther's (alleged) and C. S. Lewis' suggestion that we need to become 'little Christs' to the world. C.S. Lewis, Mere Christianity (London: Collins, 2012), 175, 190, 191, 197.

${ }^{33} C D$ IV/l, 635.

${ }^{34} C D$ IV/l, 636.

${ }^{35} \mathrm{CD}$ IV/I, 636.
} 
creation - and we see this in the prayer of faith. ${ }^{36}$ If this happens, however, this does not mean that human beings are given an agency over and above God that somehow precedes the eternal grace of God. Under these circumstances, a person continues to act according to the prior decisions that God has made for her. She acts according to the existence that God enables her to have in the particular reality for which God created her. And when she does so, her activity corresponds to how God knows that she will act in the given set of circumstances. In light of God's prior decision, no person has any freedom for or against God apart from the freedom that is granted to her, which is always the freedom to correspond to God's election to be for humanity in Jesus Christ. For Barth, there is no freedom from the situation and purpose for which the person was created. By its very essence, there can be no absolute freedom for the contingent creature.

So, Barth contends, God's final word to creation does not differ from the first. God's eternal plan does not waver according to the capricious happenings of the created order - the consummation of God's creative purposes is identical with the fulfilment of election. As God's plan for creation is tied to Jesus Christ (the perfectly obediently one in, through, and for for whom all have been things created), it remains constant. And, in and through Jesus Christ, God's grace towards creation remains constant, even when creation turns away from God.

There is no such thing as a created nature which has its purpose, being or continuance apart from grace, or which may be known in this purpose, being and continuance except through grace. Even sin, death, the devil and hell-works of God's permissive will which are negative in their effects-even these works do not constitute any exception to the general rule. For even in these God's knowing and willing are gracious, even though they take effect as negation (and in that sense are permissive). Even the enemies of God are the servants of God and the servants of His grace. ${ }^{37}$

According to Barth's doctrine of the election of grace, nothing happens apart from God's grace. There are no accidents that hinder God's ultimate plan and no occurrences that escape his purposive accompanying. So when the creature does incomprehensibly fall away from God, this testifies to three things. (1) That God creates the creature as distinct from him: the creature

\footnotetext{
${ }^{36} \mathrm{CD} I I / 1,510-11$.

${ }^{37} \mathrm{CD} I \mathrm{I} / 2,92$.
} 
is created 'out of nothing' not 'out of God'. (2) The creature 'is not physically hindered from doing this". ${ }^{38}$ And (3) God has, for some unknown reason, actively restrained himself from the subjective life of the creature, thereby purposefully allowing this circumstance to come about. That is, according to God's covenant of grace, the creature has been placed in a situation where she can choose to walk away from God-where she can choose to resist God.

\section{The Relationship of Irresistible Grace to Human Subjectivity}

As I considered in the introduction, the doctrine of irresistible grace (unwiderstehlicher Gnade) has tended to be associated with the irresistible effects that grace has on particular human beings. ${ }^{39}$ For Barth, however, such association promotes an overly anthropocentric view of grace. As Colin Gunton puts it, it promotes a kind of "semi-reified" grace: "a kind of causal agency midway between God and the creature". ${ }^{40}$ It portrays grace as a sort of gift that God passes into the possession creature, one that will achieve a certain end should it be received: a kind of device that converts those who receive it, or an energy source that inspires those who consume it. ${ }^{41}$ Such a notion of grace, for Barth, is rooted in a "godless notion of causality.",42 For Barth, grace is not some impersonal force that engages the creature as a "thing" (or "object") (Sache) causally (ursächliche) affecting another "thing," as a foot to a ball. ${ }^{43} \mathrm{He}$ asserts that, with "a true theological realism," we need to remember "that neither God nor the creature is a 'thing"". Rather, they are both "active subjects" (wirkenden Subjekte)-albeit absolutely

\footnotetext{
${ }^{38} C D$ II/1, 503-4.

${ }^{39}$ I should note that, while there are numerous references to the irresistible nature of God's grace in the Chrurch Dogmatics, Barth only refers to 'irresistible grace' once: $C D I I / 1,645$. However, given the former, it still seems appropriate to talk about the irresistible nature of grace in Barth's thought.

${ }^{40}$ Colin Gunton, Intellect and Action (Edinburgh: T\&T Clark, 2000), 77. Gunton also notes here: "Barth's great achievement is relentlessly to turn the semi-causal notion of grace into a characterisation of personal divine action."

${ }^{41}$ When grace is perceived in this way, it is not surprising that 'Arminians' feel uncomfortable about the idea of its irresistibility. See J.H. Donner and S.A. van den Hoorn, Acta of Handelingen der Nationale Synode, in de naam van onze Heere Jezus Christus gehouden door autoriteit der Hoogmogende Heren Staten-Generaal der Verenigde Nederlanden te Dordrecht in de jaren 1618 en 1619 (1885, repr. Houten, 1987), 473, 480, 489, 491, 496, 512, 527, 772, 823; see also John E. Sanders, "God as Personal," in The Grace of God, the Will of Man, ed. Clark H. Pinnock (Grand Rapids: Zondervan, 1989), 171.

${ }^{42}$ CD III/3, 118.

${ }^{43} C D I I I / 3,101$. For Barth, the "mortal danger which faces all theology" is that our discussion about God and creature ends up becoming a discussion of things or principles. He notes that we are particularly vulnerable to this danger when we follow Aquinas' Aristotelian definition of "God and the creature as primary and secondary causa." CD III/3, 101. He continues, "The human thinker and speaker is in constant danger of forgetting the inconceivable mystery of their existence and being, their presence and operation, and of imagining that he can think and speak about them directly, as though both they themselves and also their relationship to each other were somehow below him." CD III/3, 102.
} 
incomparable subjects. ${ }^{44}$ God's grace is a personal activity, which, in Jesus Christ and by his Spirit, freely engages human beings, active subject to active subject. ${ }^{45}$

We again have to remember, however, that human beings never interact with God horizontally, on the same plane, because the creator-creature distinction never collapses. ${ }^{46}$ This means that the human person can never create correspondence with God for herself but always depends upon divine acts of mediation-upon the Spirit drawing her to participate in the reconciliation that has been accomplished in Jesus Christ. When this happens, God's grace is irresistible because it precedes the tide of human activity. God encounters that person before she can cover her eyes; God speaks to her before she can cover her ears; God humbles her before she can embrace her pride; and God animates her before she can turn to sloth. God acts towards her in this way because he chose her in Christ before the foundation of the world to be holy and blameless towards him in love (Eph. 1.4), and because God has knitted her together in our mothers' wombs to be his covenant partner in Christ. All this takes place before a person has the capacity to resist. Again, however, the precedence of God's grace does not mean that God's grace is necessarily effectual. As I discuss below, its preceding operation does not necessarily achieve the kind of positive results that align with the covenant life that God elects for the creature. However, when it fails to do so, it fails precisely because God has graciously created a set of circumstances in which God graciously allows resistance to be a possibility. In this way, God's apparent "inactivity" is just as attached to the covenant of grace as his activity.

\footnotetext{
${ }^{44} C D$ III/3, 101-2; KD III/3, 115 (emphasis in the original German text). A similar case is made previously by Dietrich Bonhoeffer in his lectures on Christology when he writes, "the relation between God and human being should be understood never as the relation between two things but [only as that] between two persons." Bonhoeffer, Dietrich Bonhoeffer Works 12: Berlin 1932-1933, trans. Isabel Best and David Higgins, ed. Larry Rasmussen (Minneapolis: Fortress Press, 2009), 352.

${ }^{45}$ CD III/3, 102; see also Barth's response to G.C. Berkouwer's The Triumph of Grace in CD IV/3, 174-76 (in particular). In light of Barth's emphasis here, it seems an overstatement for Jesse Couenhoven to draw the conclusion that "Barth's primary emphasis is on grace as pardon [rather than power]." Couenhoven, "Grace as Pardon and Power," Journal of Religious Ethics 8 (2000), 83; Gerald McKenny also calls this conclusion into question. See McKenny, The Analogy of Grace: Karl Barth's Moral Theology (Oxford: Oxford University Press, 2010), 200 n. 113.

${ }^{46}$ For this reason, Barth takes a firm stance against the notion of a reciprocal relationship between God and humanity. For him, "[t]here can be no thought of any reciprocity or mutual efficacy [Wechselwirkung] [between humanity and Jesus Christ] even with the most careful precautions. Faith in particular is not an act of reciprocity, but the act of renouncing all reciprocity, the act of acknowledging the one Mediator, beside whom there is no other." (CD I/2;KD I/2, p. 162). That said, when Barth makes this statement he is denying the possibility of any independent or unmediated interaction between (the true) Jesus Christ (of faith) and humanity - the kind of interaction that takes place directly between two persons on the same plane (which could, very cautiously, be said to take place between a creature and the merely human 'Jesus of history'). In light of this, the Church Dogmatics helpfully translates Wechselwirkung as 'mutual efficacy' rather than 'interaction'.
} 
So much so that Barth thinks it can be appropriate to associate God's inactivity with his activity. $^{47}$

When we become clear that, for Barth, God's gracious activity towards creation is grounded in and mediated through the person of Jesus Christ, we can begin to see why, for Barth, grace cannot be reduced to a physically causative activity by which divine agency eliminates human agency. ${ }^{48}$ For Barth, persons encounter grace as it is mediated to creation in and through the person of Jesus Christ. As such, the grace of God relates to human beings in a human-to-human correspondence with God that is enabled by the Holy Spirit. While this interaction is totally unique from natural human-to-human interactions, it is nonetheless characterised by an involvement from both sides in which human beings maintain their own particular identities and agencies. Accordingly, it is overly simplistic for John Macken to suggest, alongside Hans Urs von Balthasar, that human beings are "a mere epiphenomenon of divine grace and of the divine will." ${ }^{49}$ For Barth, "grace would no longer be grace if its exercise consisted only in the elimination or suppression as an autonomous subject of the one to whom it was extended." ${ }^{50}$ Rather, Barth understands that God's causal activity "consists, and consists only, in the fact that He bends their [creatures'] activity to the execution of His own will which is His will of grace, subordinating their operations to the specific operation which constitutes the history of the covenant of grace." ${ }^{51}$ And he does this in and through the person of Jesus Christ.

\footnotetext{
${ }^{47}$ See $C D$ III/3, 120-1. Accordingly, Eberhard Busch notes, "Barth teaches an essential God-relatedness on the part of every human, based in the grace of God;" as such, "the god-less human cannot render God humanless"there is "no 'below' shut off from God." Busch, The Great Passion: An Introduction to Karl Barth's Theology, trans. G.W. Bromiley, eds. Darrell Guder and Judith Guder (Grand Rapids: Eerdmans, 2004), 91.

${ }^{48} \mathrm{CD} I I I / 3,149$.

${ }^{49}$ John Macken, The Autonomy Theme in the 'Church Dogmatics' (Cambridge: Cambridge University Press, 1990), 157. Von Balthasar also suggests, "Barth ends up talking about Christ so much as the true human being that it seems as if all other human beings are mere epiphenomena." Hans Urs von Balthasar, The Theology of Karl Barth, trans. E. T. Oakes (San Francisco: Ignatius, 1992), 243; see also Terry Wright "Reconsidering Concursus," International Journal of Systematic Theology 2:2, (2002), 210.

${ }^{50} \mathrm{CD} I I I / 3,93$.

${ }^{51} C D I I I / 3,105 ; K D I I I / 3,114-5$. The term "bends" is very much an introduction by the English translators, but it does work in this context. This is supported by the fact that Barth uses the German equivalent "beugt" in a similar way in CD I/l when he notes that God's Word comes to us in such a way that it "bends [beugt] man, and indeed his conscience and will no less than his intellect and feeling-it does not break him; it really bends [beugt] him, brings him into conformity with itself." $C D I / 1,206 ; K D I / 1,215$.
} 


\section{The Divine Permitting}

While Barth denies that the grace of God eliminates human personhood, he does think that there

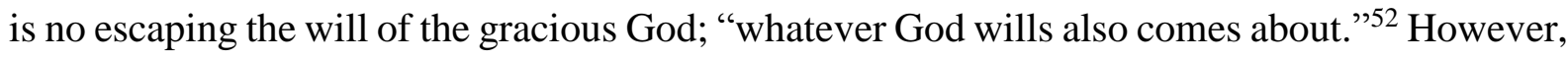
in holding to this view, Barth dissociates himself from "the dreaded conclusion that... God can and must be thought of as the author of evil". ${ }^{53}$ And, again, he denies that creaturely activity is merely an expression of God's grace. To avoid these conclusions, he acknowledges that God's will does not confine itself to efficere (effecting). ${ }^{54}$

There is a divine volition which is no less real and powerful, no less righteous and good and no less omnipotent than His affirmative will, but of a very different character. This is the volition of God in virtue of which He not only gives the creature its existence and being, the independence and freedom which belongs to it and therefore its true creaturely existence, but in virtue of which, because he wills its free obedience and therefore its blessedness, He refrains from making absolutely impossible the misuse of its independence and freedom, and therefore the incapacitating and destruction of its creaturely existence... God wills to create, cause, and produce in such a way that He also 'permits.

Barth draws a clear distinction between the negative aspects of creaturely existence that God decisively permits, but does not affirm, and the positive aspects that God affirmatively brings about. He is clear that the person who sins does so against and in resistance to the grace of God. At the same time, he also recognises that God graciously, and by his good will, permits the creature to exist in a situation in which sin is a possibility - albeit one that he describes as an impossible possibility. To this extent, Barth accepts that God's grace is the presupposition of the creature's $\sin .{ }^{56}$ Yet he also views it as a presupposition that neither leads nor compels the

\footnotetext{
${ }^{52} C D I I / 1,596$.

${ }^{53} C D I I I / 3,121$.

${ }^{54} C D I I / 1,594$.

${ }^{55} C D$ II/1, 594. Also, Barth later writes in CD IV.4: "the omnicausality [Allwirksamkeit] of God must not be construed as His sole causality [Alleinwirksamkeit]." CD IV/4, 22; KD IV/4, 25.

${ }^{56}$ For Barth, God is actively involved in both the positive and negative aspects of creaturely existence, such that nothing takes place within creation as the result of inactivity on God's part. If, therefore, "God permits it [evil] and therefore effectively wills His creature to assume this character, this is His good and righteous will and serves to increase His glory." However, he then qualifies that God's "will in this activity does not make the evil good or make it His own as evil. For in this activity it is a wholly negating will, permitting in power but only permitting and not affirming." $C D I I / 1,597$.
} 
creature to sin, but actively opposes it. Sin arises because God graciously restrains himself from the creature. As such, sin "has no basis in grace." ${ }^{57}$ Indeed, Barth goes so far as to say that "[s]in resists grace; it affronts it and betrays it." 58

For Barth, however, God only permits this resistance for a time and will ultimately "smash" any opposition to his love. God is ever faithful to his covenant of grace. ${ }^{59} \mathrm{We}$ are, therefore, "forbidden to take sin more seriously than grace, or even as seriously as grace". 60 While God allows the creature to exist as the subject of sin and faithlessness, this subjection needs to be recognised as constantly subject to God's lordship over creation. While the individual "may let go of God," "God does not let go of him."61

Even in Barth's excursus on Judas in CD II/2, Barth does not view Judas as resisting the "irresistible divine grace of Jesus Christ". ${ }^{62}$ While Judas might reject the grace of God, and while Judas might live as a "rejected" man "who isolates himself from God by resisting his election as it has taken place in Jesus Christ," 63 Judas never possesses any power over the grace that precedes his defiance. His rebellion, therefore, has no power to determine the nature of God's grace for him. His rebellion that refuses (and therefore lacks) God's grace is nothing; it is both fatal and futile. ${ }^{64}$ So when Judas lives as the "rejected" man, the situation is as follows: "God is for him; but he is against God. God is gracious to him; but he is ungrateful to God. God receives him; but he withdraws himself from God." 65

\section{The Divine Accompanying}

As I noted above, there can be a danger in some areas of Christian thought to reduce the grace of God to an impersonal agent of human change. Barth does not make this error. Yet he does not ignore the question of what it means for human activity to accompany grace. To pursue this question, he turns to the doctrine of the concursus Dei: the doctrine that deals with God's accompanying of the creature - that deals with "the Lordship of God in relation to the free and

\footnotetext{
${ }^{57} \mathrm{CD} I I I / 2,35$.

${ }^{58} \mathrm{CD} I I I / 2,35$.

${ }^{59} \mathrm{CD} I I / 2,27$.

${ }^{60} \mathrm{CD} I I I / 2,41$.

${ }^{61} C D I I / 2,317$

${ }^{62} \mathrm{CD} I I / 2,477$

${ }^{63} C D I I / 2,449$.

${ }^{64} C D I I I / 3,353 ; C D I I / 2,452$; see also $C D I I I / 3,349$.

${ }^{65} C D I I / 2,449$.
} 
autonomous activity of the creature". ${ }^{66}$ To develop this doctrine, he turns to the human freedom of Jesus Christ.

Basically, the doctrine of the concursus must be as follows. God, the only true God, so loved the world in His election of grace that in fulfilment of the covenant of grace instituted at the creation He willed to become a creature, and did in fact become a creature, in order to be its Saviour... [As such] He co-operates with it, preceding, accompanying and following all its being and activity, so that all the activity of the creature is primarily and simultaneously and subsequently His own activity, and therefore a part of the actualisation of His own will revealed and triumphant in Jesus Christ. ${ }^{67}$

It is through participation in Jesus Christ that persons share in the covenant of grace and eo ipso learn what it means to participate in this covenant. Barth's account of the concursus Dei, however, is not merely christological, it is also explicitly trinitarian. By looking to the triune economy and, in particular, to the work of God's Spirit, Barth develops an account of the concursus Dei that is not marked by an impersonal interobjectivity. His account does not present God (the causa causarum) as accompanying and effecting the creature from the transcendent objectivity of an isolate Jesus Christ or an isolate eternal Creator. That is, while Barth acknowledges a basic concursus in "the relation between the Creator who is gracious and the creature which receives His grace, ${ }^{, 68}$ he also affirms that this more detached concursus is inseparable from a providential concursus, according to which the living God graciously accompanies a person with the purpose of drawing her into participate the covenant of grace by the power of the Holy Spirit. ${ }^{69}$ When the creature responds to this accompanying, her response is not a forced reaction but a response of gratitude. "Grace and gratitude belong together like heaven and earth. Grace evokes gratitude like the voice of an echo. Gratitude follows grace like thunder lightening."70

\footnotetext{
${ }^{66}$ CD III/3, 90. For two penetrating analyses of Barth on the concursus Dei, see Paul Nimmo, Being in Action (London: T\&T Clark, 2007), 118-30 and his article 'Karl Barth and the Concursus Dei-A Chalcedonianism Too Far?' in International Journal of Systematic Theology 9:1 (2007), 58-72.

${ }^{67} \mathrm{CD}$ III/3, 105. Barth qualifies further, "God 'concurs' with the creature, but the creature does not 'concur' with God. That is, the activity of the creature does not impose any conditions upon the activity of God. As against that, the 'concurrence' of God with the creature, being His own and absolutely supreme, means that the activity of God conditions absolutely the activity of the creature." $C D$ III/3, 112-13.

${ }^{68} \mathrm{CD} I I I / 3,133$.

${ }^{69} \mathrm{CD} I I I / 3,117$; see also $144-45$.

${ }^{70} \mathrm{CD}$ IV/I, 41.
} 
When the creator-creature connection is construed in light of the creation-providence connection, Barth insists that we cannot think about the concursus divinus with "the mathematical picture of two parallel lines." ${ }^{, 71}$ For him, God would not be God "if there were a single point where He was absent or inactive, or only partly active, or restricted in His action."72 Also, because God creates ex nihilo, he affirms that every facet of creation requires to be understood with reference to the covenant of grace fulfilled in Jesus Christ. It would be impertinent to suggest otherwise. This leads him to say that "creaturely events take place as God Himself acts," and God's "will is accomplished directly and His decisions are made and fulfilled in all creaturely occurrence both great and small." 73 Furthermore, he reminds us that this all takes place according to God's creative purposes: "The history of the covenant of grace accompanies the act of the creature from first to last."74

To put this in context, Barth considers that when I bring about a change or effect through a speech event, God "decided concerning my word even before I uttered it. He decides concerning it at the very moment when I utter it. And He will decide concerning it, what it is and what it means, after I have uttered it." ${ }^{, 75}$ That is, God purposefully creates the circumstances in which I speak; God purposefully accompanies me in a way that defines, maintains and allows for the circumstances in which I speak; and God purposefully follows me in a way that defines, maintains and allows for the circumstances in which my word becomes heard. However, Barth does not merely suggest that God creates my surroundings, he also asserts that the particular "I" who speaks is a part of the created, defined, maintained, and allowed circumstances. ${ }^{76}$ In light of this, he does not deem it inappropriate to describe the actual effect of my speech as both "my effect" and "a divine effect". ${ }^{77}$ Nor does he see it as incorrect to go further and suggest that "we have to understand the activity of God and that of the creature as a single action" ${ }^{78}$ For Barth, human action is never divorced from God's purposive acts of creating, defining, maintaining, and allowing, nor is it divorced from Christ's fulfilment of God's covenant purpose.

\footnotetext{
${ }^{71} C D I I I / 3,133$.

${ }^{72} C D I I I / 3,133$.

${ }^{73} \mathrm{CD} I I I / 3,133$.

${ }^{74} C D I I I / 3,92$.

${ }^{75} \mathrm{CD}$ III/3, 153. Barth continues, God "decides concerning the form and compass and meaning and range of this fact, concerning the content and meaning and power of the word which I have spoken as a creature and my fellowcreatures have received as such."

${ }^{76}$ However, as a part of these circumstances, the "I" is created, ruled and loved as a singular individual who speaks with "its own independent significance and validity, its own independent value and dignity. " $C D I I I / 3,173$.

${ }^{77}$ CD III/3, 153.

${ }^{78} C D I I I / 3,132$.
} 
In holding to this position, Barth is not pastorally naive to the theodic difficulties. However, he does not respond to these difficulties by speculating about possible scenarios that can explain why God interacts with creation in the way that he does-why God currently allows his children to suffer. He responds by persistently acknowledging the mystery of grace, before which we cannot know how or why God (purposefully) permits the horrors of this world. ${ }^{79}$ Also, he responds with lamentation. ${ }^{80}$ And, to an extent, he responds with silence. However, what he does say is that, in Jesus Christ, God more than knows our pain, and takes this pain to himself. ${ }^{81}$ Also, with a knowledge of God's love for the world, he affirms that we can trust that our situation is "in good hands". ${ }^{82}$ For Barth, our distress and lamentation is always overshadowed by the redemption that God has achieved for creation, as the resurrection overshadows the cross.

In response to Barth's doctrine of the concursus Dei, Terry Wright comments: Barth "emphasizes God's lordship over creation to such a severe degree that we may doubt, and reasonably so, that the divine activity establishes creaturely freedom in the way he insists." $" 83$ However, for Barth, it is precisely because of God's unconditioned lordship over creation that the creature can enjoy the freedom that it does. For Barth, the creature does not exist a se. Unlike God, the creature is not a creature in, of, and from itself eternally. The creature is created by God. As such, it only ever enjoys the freedom that it does because God has irresistibly allowed the creature to have that freedom. Again, for Barth, every substantive aspect of creation is filled with a fixed purpose that corresponds to God's covenant of grace. God has not ordained any other ends for the cosmos. Every contingent aspect of creation corresponds to God's free decision to create, maintain, and allow the circumstances in which everything takes place. Therefore, it is not counterintuitive for Barth to insist that there can be no real competition between God's grace and human works. For matters to be otherwise, God would need to be somewhat deistic or purposeless in his creative activity: purposelessly and gracelessly allowing the creature some freedom to be a second creator, to create and rule over its own independent purpose rather than be governed by the grace of God. That is, God would randomly need to grant persons the autonomy to create "definitive collateral goals which can be finally sought and attained side by side with or apart from the goal which God Himself has appointed". ${ }^{84}$

\footnotetext{
${ }^{79}$ See $C D I I I / 2,138-40$.

${ }^{80}$ See $C D I V / 3,145,179$.

${ }^{81}$ See $C D I I / 1,373-4$; and $C D I V / 1,265-67,487$.

${ }^{82} \mathrm{CD} I I I / 3,154$.

${ }^{83}$ Terry Wright, "Reconsidering Concursus," 210.

${ }^{84} \mathrm{CD} I I I / 3,158$.
} 
In remaining consistent on this point, Barth asserts that even when the creature revolts, she does so as a result of God's creative purposes; even in these acts she cannot escape the covenant of grace. He admits that the problem of chaos, sin, evil, the devil, and demons can appear to have "something like an autonomous collateral government, or counter-government"-a power that is "at work, limiting and compromising the sole rule of God." 85 However, he does not hesitate to reject this perception: "No matter how seriously we have to take this particular factor [revolt against God], we cannot in any circumstances ascribe to it the dignity of a second creator and ruler of the universe. We do not take it seriously by conceding more to it than the

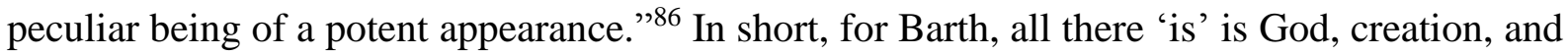
nothing; there is therefore no thing to create, define, maintain and allow creaturely freedom that is apart from the purposive grace of God.

\section{The Compatibility of Divine and Human Freedom}

When coming to terms with Barth's account of the concursus Dei, it is very tempting to associate his position with a compatibilist notion of human freedom, which affirms compatibility between human free will and divine (causal) determinism. ${ }^{87}$ Such a labelling, however, risks associate Barth with any number of different positions-particularly given that the notion of 'compatibilist freedom' is so loosely defined. In particular, this charge risks tying Barth to (what he sees as) the Augustinian notion of freedom of which he was so critical: to the understanding that human determination is really the same as divine determination, just interpreted differently from different perspectives-interpreted as freedom from the human side and grace from the divine side. ${ }^{88}$

The problem with associating Barth with a compatibilist notion of freedom becomes apparent in Nigel Biggar's attempt to do so. According to Biggar, Barth holds that "human beings are determined to choose freely what is right." ${ }^{\text {" }}$ He then writes: "This yields a notion

\footnotetext{
${ }^{85} \mathrm{CD} I I I / 3,158$.

${ }^{86} C D I I I / 3,158$. Barth later argues that sin is the creature's "surrender to the alien power of an adversary." (CD $I I I / 3,158,310)$. He then qualifies this by saying "Sin could not be grounded in human freedom if it had no divine causality. Sin, too, is posited with free self-development and therefore in virtue of the divine ordination." Nevertheless, he continues, "there is no divine causality of sin; it simply does not exist for God." (CD III/3, 321). ${ }^{87}$ See Jesse Couenhoven, "Karl Barth's Conception(s) of Human and Divine Freedom(s)," in Commanding Grace, ed. Daniel Migliore (Grand Rapids: Eerdmans, 2010), 246-51; David Fergusson, 'Will the Love of God Finally Triumph?' in Nothing Greater, Nothing Better: Theological Essays on the Love of God, ed. Kevin J. Vanhoozer (Grand Rapids: Eerdmans, 2001), 195); and Oliver Crisp, Retrieving Doctrine (Downers Grove: InterVarsity Press, 2010), 123-26.

${ }^{88}$ CD I/1, 199-200.

${ }^{89}$ Nigel Biggar, The Hastening that Waits (Oxford: Clarendon Press, 1993), 5.
} 
of human freedom that is more apparent than real, and it raises questions about the graciousness of a grace that does not concede to the beloved the freedom to turn away permanently." 90 The first thing to point out here is that Barth would object to Biggar's confusing God's grace with a relative human conception of graciousness. This point aside, Biggar's presentation of Barth is is superficial. On the one hand, it is fair to affirm that Barth believes that God has determinatively, purposefully, and fixedly created the creature for a life of right relationship with God: a life that is only realised by God's mediatory and thus determinative activity, in and through the person of Jesus Christ. On the other hand, however, it is not valid to deduce from this that, for Barth, human beings only participate passively in the drama of creation. Barth consistently presents the person as both an active and self-determining subject who chooses the truth freely (if she does so). That is, in accordance with her knowledge of the truth, the human is a subject who comes to make her own decision to live in correspondence to the covenant of grace, as the Holy Spirit delivers her to discover her true humanity in Christ.

What Barth does deny is the possibility of a person possessing a self-transcendent autonomy. While persons are autonomous, they cannot transcend the particular will that drives them to make the particular decisions that they do. ${ }^{91}$ Barth is well aware that the free person is a single self who (in a particular moment) can only ever be inclined to go in one direction: in a particular moment, she cannot choose what she would not choose. This means that the freedom with which the creature participates in creation history is never a totally neutral freedom to go either way. Therefore, a person can either be a faithful self, who knows the truth as the truth and thus embraces it, or a faithless self, who does not know the truth as the truth and thus rejects it. A person cannot know the truth as the truth for her and then proceed to embrace untruth. ${ }^{92}$ Accordingly, when a person makes the decision of faith-when a person says 'Yes!' to God-it is not because she has arbitrarily chosen the truth of God's Word. Nor is it because she has actively imagined God and dreamed up her own response to him. It is because the Spirit, doctor veritatis, ${ }^{93}$ has made this truth known to her and thereby turned her denying self into an accepting self. ${ }^{94}$ The decision of faith, therefore, belongs to "the work of

\footnotetext{
${ }^{90}$ Nigel Biggar, The Hastening that Waits, 5. This passage is also critiqued by John Webster in Barth's Ethics of Reconciliation (Cambridge: Cambridge University Press, 1995), 226-27.

${ }^{91}$ Given Barth's acknowledgement of human autonomy, David Fergusson needs to provide some more conceptual clarity when he writes, "Human autonomy is generally excluded by Barth because of its inevitable association with synergism or semi-pelagianism that will compromise the sovereign grace of God." (Fergusson, "Will the Love of God Finally Triumph?," 195).

${ }^{92} \mathrm{CD} I I / 2,27$.

${ }^{93}$ CD I/1, 451; Tertullian, De praescritione haereticorum, 28.

94 This decision should not be compared to a person's decision to embrace $1+1=2$, which, once taught, a person can know for herself by her own rationale in abstraction from the teacher.
} 
the Holy Spirit which happens to us... We have no power over it; it is not at our disposal."95 In this dynamic, we actively participate in our decision of faith but we do not have any selftranscendent control over it. This decision is thus an inevitable response to the irresistible grace of God; the activity of the creature "can only be a [nur eine sein kann] confirmation [Bestätigung] of the divine activity." 96 He writes:

The freedom of its [the creature's] activity does not exclude but includes the fact that it is controlled by God. It is God who limited it by law and necessity and it is God who created it free. And it is also God who in preserving it gave to it a sphere in which to exercise its freedom. And it is also God who in accompanying it through time is the Lord of the use which it is able to make of its freedom. It does use this freedom. It is active at every moment. But in every moment it uses this freedom on the basis of the particular divine permission to do so. It works always within the framework and the limits of this permission. ${ }^{97}$

Convinced that the creature is created with a freedom to choose what is true to herself, Barth does not see it as a denial of human freedom to go one step further and define true freedom as the freedom to choose what is true to her true self, as it is defined according to the covenant of grace. As I shall now briefly discuss, Barth insists that true human freedom does not entail 'the power of contrary choice'- the freedom to act either according to or contrary to our created nature. Rather, it is the freedom to be true to the true self one was created to be, and, therefore, essentially is. ${ }^{98}$ Thus the creature is only truly free when its will is "based on and governed by God's knowledge," and when it is free in this way, its will is "free and responsible in itself". 99 For Barth, this happens when "God's will meets us as omnipotent will, as a free and irresistibly and finally compelling power confronting our own will, as a decisive determination not of this or that but of ourselves, as our own determination to obedience to it." 100

\footnotetext{
${ }^{95}$ Barth, 'The Sovereignty of God's Word and the Decision of Faith,' in God Here and Now, trans. P.M. van Buren (London: Routledge \& Kegan Paul, 1964), 22.

${ }^{96} C D$ III/3, 94; KD III/3, 107 (translation altered). In his helpful comparison between Luther and Barth, Eberhard Jüngel notes that, for Luther, "God acts, and we receive (and only then can we begin to act). For Barth, where God acts, we are seen to act-precisely in receiving." Eberhard Jüngel, "Gospel and Law," in Eberhard Jüngel, Karl Barth: A Theological Legacy, trans. Garrett E. Paul (Philadelphia: Westminster Press, 1986), 124.

${ }^{97} \mathrm{CD}$ III/3, 165-66.

${ }^{98} C D I I / 1,586$.

${ }^{99} \mathrm{CD} I I / 1,578$.

${ }^{100} \mathrm{CD} I \mathrm{II} / \mathrm{l}, 588$.
} 


\section{The Irresistible Call to Faith}

Given that debates over the irresistibility of grace have tended to revolve around the effectuality of the Spirit's call, it would be appropriate to mention briefly Barth's understanding of the relationship between irresistible grace and the call to faith: the call of Jesus Christ that is so "majestic and penetrative... that when it is heard as such, when we know and discern that it is He who calls us, it is irresistible". ${ }^{101}$

In what way, for Barth, is the call to faith irresistible? It is irresistible for two reasons. First, it comes to us from the person of Jesus Christ whose agency is beyond our control. And, second, if the call of Christ is heard as the call of Christ that is true to our humanity, we cannot resist it because, in our single-mindedness, we cannot deny what we fully recognise to be true to our humanity. The only way for us to deny what we fully perceive as truth is by coming to perceive it as untruth in a subsequent act of forgetfulness. Such a move, however, does not resist the grace of Christ's call but resists our own confused idea of Christ's call - an idea created by our sinful imaginations. When we hear Christ's call by the power of the Holy Spirit, it "calls us to faith which cannot possibly be faithlessness, repentance which cannot possibly be renounced, to faith which is indestructible and quite incapable of changing into its opposite." 102 The relationship that our faith has to the person of Jesus Christ, for Barth, is not a matter of personal preference, nor is it open to interpretation. Faith arises when we hear and accept an objective fact in the event of our calling. The faith that "is irresistibly awakened" from within us "confirms and accepts the fact of our sanctification"- a fact that is true before a person comes to accept it existentially (in nobis). ${ }^{103}$

Accordingly, Barth rejects the notion of a "temporal sequence," or ordo salutis, which interprets the grace of sanctification psychologically according to the spiritual experience of the Christian. ${ }^{104}$ For Barth, it is only by the prevenient grace of God that it is possible for individuals

\footnotetext{
${ }^{101}$ CD II/2, 779. Interestingly, Barth's position finds alignment with John Wesley who writes, "the grace which brings faith, and thereby salvation into the soul, is irresistible at that moment. That most believers may remember some time when God did irresistibly convince them of sin. That most believers do at some other times find God irresistibly acting upon their souls." John Wesley, The Works of the Reverend John Wesley A. M. (New York: J. Emory and B. Waugh, 1831), 480-81.

${ }^{102} C D I I / 2,779$.

${ }^{103}$ CD II/2, 779, 779-80. "In this faith," Barth adds, "Jesus Christ Himself lives in us-the Head in His members, the "author of faith" in His followers." CD II/2, 780.

${ }^{104}$ For Barth, justification and sanctification are not "steps in a so-called ordo salutis, preceded by a vocatio and illuminatio, and followed by the separate processes of regeneratio and conversio, and then (in the Lutherans) by a unio mystica and glorificatio." CD IV/2, 502. With Calvin, he maintains that the "simul of the one redemptive act of God in Jesus Christ cannot be split up into a temporal sequence, and in this way psychologised." $C D I V / 2$, 507. (He does add, however, that we cannot totally lay aside the question of order).
} 
to become saints, by participating in the sanctity of Christ. That is, individuals can only come to faith when God's Word encounters them in the power of the Spirit-which Barth associates with the power of revelation and the power of the resurrection. This is the power of the Gospel. By this power, the good news is made known as good news; God's good purposes are made known as good purposes; and the creature is given to know who she was created to be as the one she was created to be. In this way, it is a power that is both true to the speaker and the hearer, to the object of faith and the subject who is drawn into faith: "when we are summoned and empowered to believe in God... [we do] so in the relation of claim and response, of speaking and hearing, of command and obedience, which both objectively and subjectively God Himself has instituted and ordained." 105 In this way, the grace of God irresistibly accompanies the creature.

Just as God Himself is respected by reason of His unconditioned and irresistible activity, the activity of His grace, so He respects as such the creature to whom He is gracious. That creature cannot ask for itself anything better than to be ruled absolutely by the divine activity of grace. If this activity were to cease or pause, if God were to reveal to the creature a sphere in which it would be something other than the object of His grace, then there would be every reason to fear for its freedom and rights and honour and dignity. ${ }^{106}$

Barth then goes on to write: "Where the Word and Spirit are at work unconditionally and irresistibly, the effect of their operation is not bondage but freedom. We could almost put it in this way, that the bondage which results from the operation of the Word and Spirit is itself true freedom."107 Again, when the Spirit gives us the eyes to see the truth as truth this is not something we can readily resist. And being given the ability to see things the way they truly are certainly does not undermine our freedom. Just as it would be strange for a person to suggest that a teacher undermines the freedom of the student by showing her the truth, it is strange to suggest that God undermines the freedom of the creature by awakening her into faith, particularly when God has created her for this truth. To this extent, the "freedom of the creature's activity... includes the fact that it is controlled by God." ${ }^{108}$ As we have seen,

\footnotetext{
${ }^{105} \mathrm{CD} I I I / 3,142$.

${ }^{106}$ CD III/3, 149.

${ }^{107} \mathrm{CD} I I I / 3,150$.

${ }^{108}$ CD III/3, 166.
} 
however, this is not an abstract or mechanistic control but a "guiding in" (Einweisung) that is always true to both the freedom and essence of the creature, which is defined according to the covenant of grace. ${ }^{109}$

\section{Conclusion}

By turning to Barth, we are given a way to move beyond some of the popular notions of irresistible grace in which grace is primarily associated with the effect that it has on particular human beings. Instead, Barth's theology of grace primarily associates grace with God's free and beneficent activity. In this theology, the grace of God creates and accompanies the creature in a way that is always true to God and his purposes, as they are fulfilled in Christ. Barth maintains that it must always be with respect to God's covenant purposes that the creature comprehends its own purpose. As I have also sought to show, however, Barth does not view the grace of God as the activity of a solo artist who determines the history of creation by himself - making every historical occurrence a mere extension of grace. Rather, it is the activity of a potter who works with the living creatures he has created (in his image), shaping them into the purpose for which they were created. For Barth, the creature is not merely the static object that clay is to the potter. Rather, the creature is a material that is dynamic and personal and takes on its own life precisely as God's covenant partner, in and through Jesus Christ by the Holy Spirit. And when "God confronts humans," he confronts them "as their Primal Origin [Ursprung], not as their immediate cause." 110 As the source that creates them for a free and loving fellowship, the grace of God confronts us as a personal activity that is true to our very essence, and that eo ipso affirms and realises our true freedom and integrity.

\footnotetext{
${ }^{109}$ CD IV/2, 363-77; KD IV/2, 405-22 (translation altered).

${ }^{110}$ Karl Barth, The Epistle to the Romans, 6th edn., trans. Edward Hoskyns (London: Oxford University Press, 1933), 357. Barth elaborates here: "Whenever it is possible for us to point to the existence of human independence or freedom, we are in fact simply deferring the problem of primal origin, of the right and freedom of God, the problem of beginning and end, creation and redemption."
} 